\title{
Labor Market Consideration as Course Selection Criteria among First Year Students in a Faculty in a Malaysian University
}

\author{
Thirunaukarasu Subramaniam \\ Department of Southeast Asian Studies, Faculty of Arts and Social Sciences, University of \\ Malaya, Kuala Lumpur, Malaysia \\ Mohammad Raduan Mohd Ariff \\ Department of Southeast Asian Studies, Faculty of Arts and Social Sciences, University of \\ Malaya, Kuala Lumpur, Malaysia \\ Hanizah Idris \\ Department of Southeast Asian Studies, Faculty of Arts and Social Sciences, University of \\ Malaya, Kuala Lumpur, Malaysia
}

Accepted: February 09, 2012 Published: April 21, 2012

Doi:10.5296/ijhrs.v2i1.1679 URL: http://dx.doi.org/10.5296/ijhrs.v2i1.1679

\begin{abstract}
This paper aims to identify factors that are considered by the first year undergraduate students from Faculty of Arts and Social Sciences (FASS), University of Malaya in course selection process in two different stages namely pre-entry and post-entry. Findings from this study reveals that in pre-entry selection criteria, 'teacher' and 'family' factors appears to be more important. 'Labour market consideration' only appears to be the third important factor in this stage. These three factors collectively explains approximately 54 percent of the variation in pre-entry selection criteria. In post-entry selection criteria, 'peers influence', 'orientation week' and 'limited choices' factors emerged as important dimensions. These three factors in turn collectively explains approximately 49 percent of the variation in post-entry selection criteria. 'Labour market consideration' emerges only as the second last important factor in post-entry selection criteria.
\end{abstract}


Keywords: Pre-Entry; Post-Entry; Selection Criteria; Labour Market Consideration; Malaysia

\section{Introduction}

Faculty of Arts and Social Sciences (FASS) which was established in 1959 is the oldest faculty in University of Malaya and also in Malaysia. Currently this faculty facing a dilemma due to decreasing number of students. With the recent shift in the emphasis of Malaysia to focus more on science-based subjects, the intake into arts-based courses in Malaysian public universities has declined tremendously. In the 2009/2010 session, only 405 students were taken into FASS. This is in line with the Ministry of Higher Education Malaysia's policy of having the ratio of 60:40 for Sciences and Arts. FASS use to be the largest faculty in University Malaya in the 1990s with students intake for any academic year reaching approximately 1,000 students. Currently there are 11 departments and three programmes in FASS that offer majors and minors as in Table 1. With 11 departments and three programmes competing for approximately 405 students, there is possibility for uneven distribution of students in various departments and programmes. Traditional departments such as History and Geography are likely to attract more students compared to newly established departments such as International Relations and Strategic Studies, Southeast Asian Studies, East Asian Studies etc.

The process of submitting an application into a Malaysian public university starts with the announcement of public examination results namely Sijil Tinggi Persekolahan Malaysia (Malaysian Higher School Certificate). The prospective students have to submit their application within two weeks after the announcement of the results of the public examination. After a waiting period of approximately two months, at the end of June, the prospective students will be notified the outcome of their application by Student Admission Management Unit, Department of Higher Education. The successful students will prepare to get into the university and eventually attend the orientation week during the first week of July.

FASS of University of Malaya is unique in the sense that it is the only university that takes the first year student under the umbrella of FASS and eventually redistribute the students among 11 departments and three programmes that are available under the umbrella of Faculty according to the choices made by the students. The code of entry into FASS, University of Malaya is given as MA00. So, all the fourteen options available (11 departments and 3 programmes) for students are jumbled up under one single code of entry. In contrast, other public universities in Malaysia allows students to directly apply to the specific degree program that they intend to major. University Kebangsaan Malaysia (National University of Malaysia) for examples allows the students to directly apply into the majors that they intend to do. For example, entry code KA14 is given to students who intend to study Social Sciences(Anthropology and Sociology), entry code KA15 for Social Sciences (International Relations), KA18 for Social Sciences (Geography), KA24 for Arts (History) 
etc. Absence of separate entry codes for various programmes in the faculty causes students that chooses FASS of University of Malaya to make decision twice namely at pre-entry stage and post-entry stage. Pre-entry stage involves choosing eight options or programmes that are being offered in Malaysian public universities. Once the students are admitted into FASS, they will be involved in the second stage of selection known as post-entry stage. Post-entry selection stage involves FASS students only where they are required to choose two set of courses which will eventually be their major and minor in their second year.

In the first year, the students will not decide upon their major and minor. They will only start to major and minor in the second year of their studies. Thus, choosing the right course is important as it is associated with employability of the students once they get into the labour market. Data on graduate unemployment in Malaysia displays an increasing trend. In 2005, the Malaysian government announced that there were 67,000 unemployed graduates, many of whom had graduated between 2000 and 2004 and approximately $92.6 \%$ of these unemployed graduates were from public universities, as opposed to only $5.3 \%$ from private institutions (Devadason, Thirunaukarasu and Daniel, 2010). In 2008, there were 54,100 unemployed graduates in Malaysia (Malaysia Department of Statistics, 2009).

One of the issues that is often raised is mismatch between the availability of the skills and the job openings in the labour market (Mansor and Tan, 2009). Thus, choosing the right major and minor based on the demand in the labour market is very crucial for the students to ensure that they are employed once they get into the labour market. During the decision making process to choose two set of courses, individuals that interact most with these students are more likely to play a major role in their decision making. As time given to make this post-entry selection is only limited to two weeks at the beginning of the first semester, the students tend to be influenced by many parties in their decision making process.

The objectives of this study are twofold. Firstly this study aims to identify factors that determine course choosing among first year undergraduate students during pre-entry and post-entry stage. Secondly, this study aims to rank the importance of labour market aspect as one of the factor that is considered in course choosing among first year undergraduate students.

This paper is divided into five sections. The second section explores some related theories and literature, the third section looks at the data and method, the fourth section discusses the results in two stages namely pre-entry and post-entry stages and the final section concludes.

\section{Theory and related literature}

Course selection criteria involves a decision making process. Moogan et al. (1999) used Kotler's (1997) consumer buying decision process model to analyse the decision making process in course selection criteria adopted by candidates hoping to gain entry into higher 
education. The five stage model is as follows: problem recognition, information search, evaluation of alternatives, purchase and post-purchase evaluation. As course selected will determine the competitiveness of the graduates in the labour market, courses that have high demand in the labour market will benefit the graduates in terms of reducing the period of being unemployed and obtaining a job and commanding a higher wage in the labour market. Human Capital Model on the other hand proposes that an individual invests in human capital with anticipation of getting higher return in the future (Becker 1993; Mincer 1958). This portrays that the labour market consideration should be one of the main criteria in making course choice decision among tertiary level students. Thus, labour market consideration should be the major determinant in course selection criteria as this factor will determine whether one will be employed upon completion of his or her studies in tertiary level. Does students that enter the FASS in University of Malaya, Kuala Lumpur considers this factor or are there any other factors that are considered in course choosing?

Selection criteria into tertiary education in the context of our study involve two stages namely pre-entry and post-entry selection criteria. Pre-entry selection criteria comprise university and/or course selection criteria (Bratti 2003; Brown, Varley and Pal 2009; Yamamoto 2006) and student selection criteria (Harman, 1994). Pre-entry selection criteria is associated to criteria considered before a prospective tertiary student makes a decision to enter any university or course. From the perspective of students, common factors that are considered before choosing any university and course include demand in the labour market or opportunity for career advancement (Moogan, 2010). Labour market consideration involves whether the course selected will enable the students to get a job in the labour market. Other factor considered include family's influence (McDonough 1997; Yamamoto 2006). Teacher's advice is also an important factor in course selection. As prospective tertiary students, teachers are more likely to be their role models especially for students from rural areas. The chances of them following their teachers footsteps are very high. Beside parents, teachers and counsellors, peers are also likely to influence pre-entry selection criteria (Perez and McDonough, 2008).

On the other hand, student selection criteria are criterias set by the public institutions of higher learning to choose their students based on merit from some pre-university courses. In the Malaysian context, common pre-university courses used to give entry into first year by public institutions of higher learning include Sijil Tinggi Persekolahan Malaysia (Malaysian Higher School Certificate), Malaysia Ministry of Education matriculation examination, A-level, diploma or certificate qualification. The central unit that coordinates the entry into Malaysia public university is known as Student Admission Management Section or Bahagian Pengurusan Kemasukan Pelajar (BPKP) under the jurisdiction of Department of Higher Education.

Post-entry selection criteria on the other hand comprise major selection criteria (Strasser et al. 2002) and/or minor selection criteria and subject or course selection criteria (DellaGioia 2008). This criteria is used by students to select their majors or minors in the institutions of 
higher learning. FASS is unique in the sense that prospective students when submitting their application to enter university will only be able to state FASS as one of their option and not exactly the major that they intend to do. In Malaysia, FASS is the only faculty that uses a single code of entry for all its fourteen programmes. Post-entry selection criteria can be determined by peers, seniors, parents and labour market considerations or job availability (Kaynama and Smith 1996). Seniors being their role model in the university setting are also very likely to influence their post-entry selection criteria. As researches on course selection criteria from the perspective of students are very limited in Malaysia, this study intends to explore it in order to add more knowledge to the existing body of literature on course selection criteria. Furthermore, selection criteria involving two stages in the FASS context warrants an investigation.

\section{The data and the method}

\section{Sampling procedure}

Currently there are 405 first year students that were taken into FASS. This study employs Simple Random Sampling where 280 students were selected as respondents.

\section{Data collection}

A questionnaire that comprise four sections were administered to the students. First part of the questionnaire identifies the respondents background, second part looks at the family background of the respondents, third party identifies the educational attainment of the respondents, fourth part focuses on the department/programme selection criteria in two stages namely pre-entry and post-entry. A five stage Likert Scale options was given for questions in the fourth section. The options given are 1-Strongly disagree, 2-Disagree, 3-Neutral, 4Agree and 5- Strongly agree. The fieldwork was done for a week from the $19^{\text {th }}$ to the $23^{\text {rd }}$ of October 2009 at the Faculty of Arts and Social Sciences, University of Malaya, Kuala Lumpur involving first year students.

\section{Data analysis}

The data is analysed using factor analysis to identify the pre-entry and post-entry course selection criteria. Reliability tests were also conducted for both the overall data as well as individual factors by generating Cronbach Alpha value.

\section{The results}

Exploratory factor analysis(EFA) was done to ensure items with low factor loadings are removed from further analysis. Kolmogorov-Smirnov Test was also done to test for normality, and the data is found to be not normally distributed. This indicates that a non-parametric analysis should be performed. Table 2 and 3 displays the descriptive statistics for pre-entry 
and post-entry stage.

\section{Pre-entry selection criteria}

Pre-entry factors that were identified include 'teacher', 'family' , 'labour market' , 'less competition' and 'previous exposure' (Table 4). These five factors that were extracted have an eigenvalue of more than 1 (Figure 1). These five factors were also subjected to a reliability test and the corresponding Cronbach alpha values obtained ranges from 0.600 to 0.829 . 'Teacher' factor plays an important role in pre-entry selection criteria as teachers are always regarded as role models and the advice of teachers are often regarded as valuable. As more than 50 percent of the respondents surveyed in this study came from less developed states such as Kelantan, Terengganu, Sabah and Sarawak, they would rely on teachers to advise them to select courses or university. Probably they enter FASS, University of Malaya with the idea of becoming a teacher in their native state as more opportunities are available to become teachers in those states. If the person that they came into contact have some kind of attachment with University of Malaya, they are more likely to choose FASS, University of Malaya. In contrast, Yamamoto (2006) said that advising guidance teachers are not very important for candidates who would like to make their own decisions. Secondly, 'family' factor also plays an important role but it is only found to be second important factor. Parents and siblings can also contribute towards decision-making process. Close family members such as father, mother and sister or brothers can influence the decision making process of the students by giving valuable insights in the decision-making process (Yamamoto 2006). 'Labour market consideration' is found to be the third important factor for these new students in their decision making process to enter university. Krone et al. (1981) also highlighted the importance of career prospect and progression into decent employment as the most important factor in decision-making criteria. Similarly, 52 percent of respondents in Moogan (2010) stated that ambition and career opportunities as important in choosing particular subject area to study at degree level. The fourth factor is identified as 'less competition' factor. The last factor is identified as 'previous exposure' factor. Even though this factor emerged as the least important factor, it is still an important factor in the course selection process. Bratti (2003) also highlighted that performance in A-levels appear to be more important in degree subject enrolment in United Kingdom. Similarly, Stearns et al. (2010) also highlighted that in making college attendance decision, students may also take into consideration prior experiences with formal educational system. Majority of pupils in Moogan (2010) study also stated that they would select a subject that they are currently studying in school. These five factors collectively explains 72 percent of the variation in pre-entry selection criteria.

\section{Post-entry selection criteria}

For post-entry selection criteria, six factors were extracted with an eigenvalue of more than 1 (Table 5 and Figure 2). The corresponding Cronbach alpha values for these six factors range from 0.600 to 0.800 . The first factor is identified as 'peers' factor. Once in the 
university, the closest person to these new students will be their seniors where these seniors will play a role in influencing the new students. Riggs and Lewis (1980) pointed out the strong influence of friends in making choices compared to factors such as school teachers and parents. Significant roles of friends and peers in course selection was also highlighted by Roberts and Allen (1997). The second factor is identified as 'orientation week' factor. This factor is also important as during the first week students will be given briefing on the options to major and minor that are available at the Faculty. This is also a formal selling point for academic staffs at FASS. If the academic staffs are able to impress the new students with their program, then they stand a better chance of attracting a large number of student to choose their department/programme. During the orientation week, students are also normally exposed with the career opportunities that are available to graduates in the chosen major and minor. The role of orientation week in this study is quite similar to post-application visit day experience suggested by Moogan at al. (1999) and Brown, Varley and Pal (2008) as they are more likely to be influenced by academic staff and other students during the orientation week. Thus, it is not suprising that orientation week emerges as the second important factor in post-entry course selection criteria as more information becomes available. It is also important to note that Malaysian public universities do not organise any post-application visit day as British universities do. Mansor and Tan (2009) also suggested that undergraduates with higher academic achievement also feel a greater need for career information. This information is made available during orientation week for new students. The third factor is identified as 'limited choices' factor. Clashes in timetable and comfort are also considered by students in their decision-making. Labour market consideration fare much worse in post-entry stage compared to pre-entry stage. It emerged as the second last important factor in course selection criteria among first year students in FASS. These six factors collectively explains 68 percent of the variation in post-entry selection criteria.

\section{Conclusion}

This study brings to fore several interesting findings. Firstly, 'teacher' factor plays an important role in pre-entry course selection criteria as teachers are found to be the closest mentors for these students. As most of the students that enter FASS at undergraduate level comes from rural areas, school teachers will be their main role model. Also in situations where parents are less or not educated, teachers advice are normally considered very valuable. Secondly, 'peers' factor play the most important role in post-entry selection criteria as the new students tend to spend more time with their friends and seniors either in dormitory or library and they are more likely to influence the decision-making process of these new students. Finally, labour market consideration is found to be more important in pre-entry selection criteria compared to post-entry selection criteria. Teachers and parents are more likely to stress the importance of labour market outcomes in pre-entry stage. But, in post-entry stage, labour market consideration appears to be less important. The strong influence of external factors such as 'peers', 'orientation week' and other unexpected factors such as timetable clashes outweighs the importance of labour market consideration in post entry stage. Efforts need to be made to ensure students choose the right 


\section{Macrothink

course so that the problem of unemployment among graduates can be minimised. More exposure to programme of study and career opportunities at high school level will ensure that student chooses the suitable programme of study at tertiary level.

\section{Acknowledgements}

This work was made possible by funding from University Malaya Research Grant Scheme (RG062/09HNE) . 
Table 1: Majors and minors available at Faculty of Arts and Social Sciences, University of Malaya, Kuala Lumpur.

\begin{tabular}{ll}
\hline Departments & Options Available \\
\hline Anthropology and Sociology & Major and minor \\
Geography & Major and minor \\
English & Major and minor \\
International and Strategic Studies & Major and minor \\
Southeast Asian Studies & Major and minor \\
East Asian Studies & Major and minor \\
Indian Studies & Major and minor \\
History & Major and minor \\
Chinese Studies & Major and minor \\
Social Justice and Administration & Major only \\
Media Studies & Major only \\
Programmes & \\
Environmental Studies & Major and minor \\
Urban Studies and Planning & Major and minor \\
Gender Studies & Minor only \\
Other Faculties & \\
Islamic Studies, Academy of Islamic & Minor only \\
Studies & \\
Cultural Studies, Cultural Centre & Minor only \\
Malay Studies, Academy of Malay & Minor only \\
Studies & \\
Economics, Faculty of Economics and & Minor only \\
Administration & \\
Mathematics, Faculty of Science & Minor only \\
\hline
\end{tabular}

Table 2: Descriptive statistics for pre-entry variables

\begin{tabular}{llllll}
\hline Variables & $\mathrm{N}$ & Minimum & Maximum & Mean & SD \\
\hline $\begin{array}{l}\text { Courses offered in } 280 \\
\text { these Departments }\end{array}$ & 1.00 & 5.00 & 3.964 & 1.132 \\
are related to the \\
subjects that I did well \\
in the STPM exam.
\end{tabular}


that I should take these

courses

\begin{tabular}{|c|c|c|c|c|c|}
\hline $\begin{array}{l}\text { Influence of my } \\
\text { siblings }\end{array}$ & 280 & 1.00 & 5.00 & 2.100 & 0.910 \\
\hline $\begin{array}{l}\text { Influence of my } \\
\text { relatives }\end{array}$ & 280 & 1.00 & 5.00 & 2.132 & 0.931 \\
\hline $\begin{array}{l}\text { Broader } \quad \text { career } \\
\text { prospects }\end{array}$ & 280 & 1.00 & 5.00 & 3.771 & 0.823 \\
\hline $\begin{array}{l}\text { High demand for } \\
\text { graduates in these } \\
\text { areas }\end{array}$ & 280 & 1.00 & 5.00 & 3.489 & 0.785 \\
\hline Less competition & 280 & 1.00 & 5.00 & 2.825 & 0.876 \\
\hline $\begin{array}{l}\text { Courses offered are } \\
\text { not available in other } \\
\text { universities }\end{array}$ & 280 & 1.00 & 5.00 & 2.775 & 1.035 \\
\hline $\begin{array}{l}\text { Motivation from my } \\
\text { teachers }\end{array}$ & 280 & 1.00 & 5.00 & 3.046 & 1.055 \\
\hline $\begin{array}{l}\text { Information provided } \\
\text { about these } \\
\text { courses/programmes } \\
\text { by my teachers }\end{array}$ & 280 & 1.00 & 5.00 & 3.103 & 0.976 \\
\hline $\begin{array}{l}\text { Wanting to follow the } \\
\text { footstep of my } \\
\text { teachers }\end{array}$ & 280 & 1.00 & 5.00 & 2.885 & 1.091 \\
\hline
\end{tabular}

Table 3: Descriptive statistics for post-entry variables

\begin{tabular}{lllllll}
\hline \multicolumn{2}{l}{ Variables } & $\mathrm{N}$ & Minimum & Maximum & Mean & SD \\
\hline $\mathrm{I} \quad$ chose & these & 280 & 1.00 & 5.00 & 4.085 & 0.812
\end{tabular}

Departments because I am interested in the courses offered in these Departments

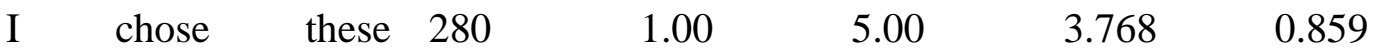

Departments because I want to explore some new areas

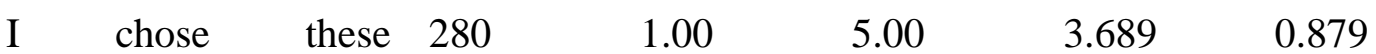

Departments because I want to try some challenging areas

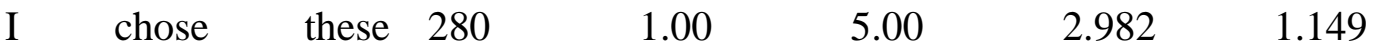

Departments because I 
want to learn a

foreign language

Influence of my peers $\quad 280$

$\begin{array}{llll}1.00 & 5.00 & 2.211 & 0.943 \\ 1.00 & 5.00 & 2.096 & 0.864\end{array}$

Influence of my 280

1.00

5.00

0.864

seniors

Previous students did 280

1.00

5.00

2.382

0.972

very well in these

Departments 280

1.00

5.00

1.764

0.876

I have limited choices 280

1.00

5.00

2.036

0.953

and lack of variety

I can arrange my 280

1.00

5.00

2.411

1.103

timetable according to

my comfort

Detailed information I 280

1.00

5.00

2.989

1.028

obtained during the

Orientation week

Most of the staffs in 280

1.00

5.00

1.936

0.865

the Department are

from the same race as

I am

Credibility and ability 280

1.00

5.00

2.875

1.162

of the academic and

non-academic staff in

the Department

Explanation provided 280

1.00

5.00

2.807

1.053

during the Orientation

week

$\begin{array}{ll}\text { Broader } & \text { career } 280 \\ \text { prospects } & \end{array}$

$1.00 \quad 5.00$

5.00

3.754

0.821

High demand for 280

1.00

5.00

3.489

0.790

graduates in these

areas

Less competition $\quad 280$

1.00

5.00

2.811

0.865

Courses offered are 280

1.00

5.00

2.754

1.005

not available in other

universities 
Table 4: Pre-entry course selection criteria

\begin{tabular}{llllll}
\hline Factors & $\begin{array}{l}\text { Factor } \\
\text { loads }\end{array}$ & Eigenvalue & $\begin{array}{l}\% \\
\text { Variance } \\
\text { explained }\end{array}$ & $\begin{array}{l}\text { Cumulative } \\
\text { Per cent }\end{array}$ & $\begin{array}{l}\text { Cronbach } \\
\text { Alpha }\end{array}$ \\
$\begin{array}{l}\text { Teacher Factor } \\
\text { Information provided about }\end{array}$ & 0.890 & & 23.993 & 23.993 & 0.829 \\
these courses/programmes by \\
my teachers
\end{tabular}

Notes: Principal components factor analysis with varimax rotation

$K-M-O$ Measure of sampling adequacy $=0.683$; Bartlett test of spherecity=1129.816; $p<0.0000$ 
Figure 1: Scree plot for pre-entry course selection crietria

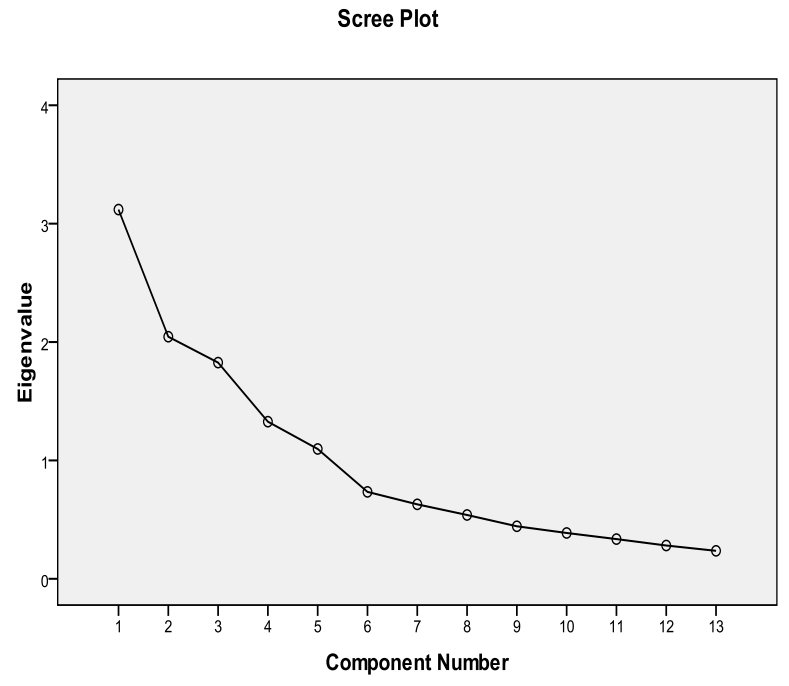

Table 5: Post-entry course selection criteria

\begin{tabular}{|c|c|c|c|c|c|}
\hline Factors & $\begin{array}{l}\text { Factor } \\
\text { loads }\end{array}$ & Eigenvalue & $\begin{array}{l}\% \\
\text { Variance } \\
\text { explained }\end{array}$ & $\begin{array}{l}\text { Cumulative } \\
\text { Per cent }\end{array}$ & $\begin{array}{l}\text { Cronbach } \\
\text { Alpha }\end{array}$ \\
\hline Peers & & 3.894 & 21.635 & 21.635 & 0.800 \\
\hline Influence of my seniors & 0.860 & & & & \\
\hline Influence of my peers & 0.801 & & & & \\
\hline $\begin{array}{l}\text { Previous students did very well } \\
\text { in these Departments. }\end{array}$ & 0.762 & & & & \\
\hline Orientation Week Factor & & 3.327 & 18.481 & 40.116 & 0.729 \\
\hline $\begin{array}{l}\text { Detailed information I obtained } \\
\text { during the Orientation week. }\end{array}$ & 0.852 & & & & \\
\hline $\begin{array}{l}\text { Explanation provided during the } \\
\text { Orientation week. }\end{array}$ & 0.823 & & & & \\
\hline $\begin{array}{l}\text { Credibility and ability of the } \\
\text { academic and non-academic } \\
\text { staff in the Department } \\
\text { Most of the staffs in the } \\
\text { Department are from the same } \\
\text { race as I am }\end{array}$ & 0.622 & & & & \\
\hline Limited Choices & & 1.508 & 8.377 & 48.493 & 0.721 \\
\hline $\begin{array}{l}\text { I have limited choices and lack } \\
\text { of variety. }\end{array}$ & 0.810 & & & & \\
\hline I have to. & 0.755 & & & & \\
\hline I can arrange my timetable & 0.737 & & & & \\
\hline
\end{tabular}


according to my comfort.

New challenges

I chose these Departments 0.777

$\begin{array}{llll}1.333 & 7.408 & 55.900 & 0.656\end{array}$

because I want to try some

challenging areas

I chose these Departments 0.763

because I want to explore some

new areas

I chose these Departments

0.5923

because I want to learn a

foreign language

I chose these Departments 0.494

because I am interested in the

courses offered in these

Departments

Labour Market Factor

$\begin{array}{llll}1.159 & 6.441 & 62.341 & 0.779\end{array}$

High demand for graduates in 0.852

these areas

Broader career prospects

0.816

Less Competition

$\begin{array}{llll}1.018 & 5.657 & 67.998 & 0.600\end{array}$

Less competition

Courses offered are not 0.731

available in other universities

Notes: Principal components factor analysis with varimax rotation

$K-M-O$ Measure of sampling adequacy $=0.736 ;$ Bartlett test of spherecity $=1759.369$; $p<0.0000$

Figure 2: Scree plot for post-entry course selection crietria

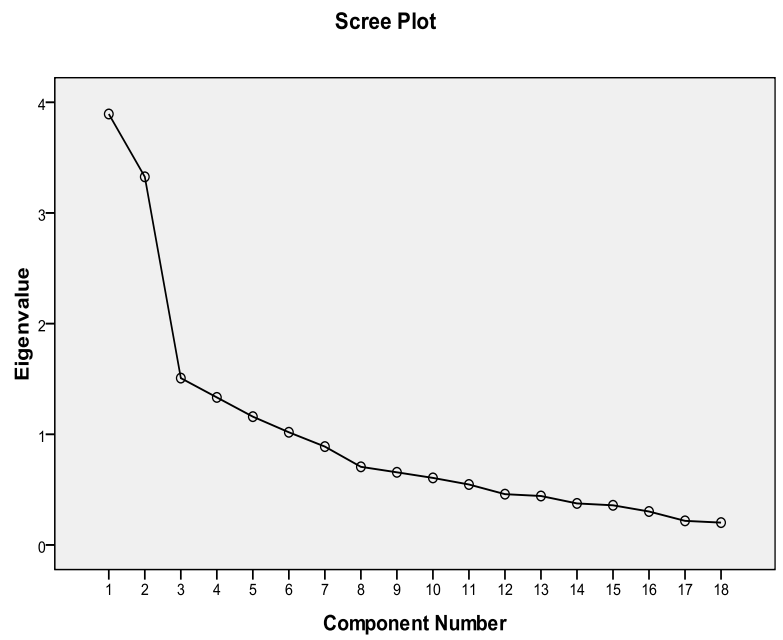


Notes on contributors

Thirunaukarasu Subramaniam is a Senior Lecturer at Department of Southeast Asian Studies, Faculty of Arts and Social Sciences, University of Malaya, Kuala Lumpur.

Mohammad Raduan Mohd Ariff is a Professor at Department of Southeast Asian Studies, Faculty of Arts and Social Sciences, University of Malaya, Kuala Lumpur.

Hanizah Idris is an Associate Professor at Department of Southeast Asian Studies, Faculty of Arts and Social Sciences, University of Malaya, Kuala Lumpur. She is also the Deputy Dean of Undergraduates at the Faculty of Arts and Social Sciences,

\section{References}

Becker G.S. 1993. Human Capital: A theoretical and empirical analysis, with special reference to education. $3^{\text {rd }}$. ed. Chicago: University of Chicago Press.

Bratti, M. 2003. Socio-economic status and field of study at the undergraduate Level in the UK. Unpublished paper.

Bratti, M. 2006. Social class and undergraduate degree subject in the UK. IZA Discussion Paper No. 1979.

Brown, C., P.Varley and J.Pal. 2009. University course selection and services marketing. Marketing Intelligence and Planning 27, no. 3: 310-325.

DellaGioia, M. 2008. Student opinion and student course selection. Journal of Undergradute Psychology Research 3:20-25.

Devadason, E.S., S.Thirunaukarasu and E.G.S. Daniel. 2010. Final year undergraduates' perceptions of the integration of soft skills in the formal curriculum: a survey of Malaysian public universities. Asia Pacific Education Review. Online First Articles, 1-28.

Harman, G. 1994. Student selection and admission to higher education: Policies and practices in the Asian region. Higher Education 27: 313-339.

Kaynama S.A. and L.W. Smith. 1996. Using consumer behaviour and decision models to aid students in choosing a major. Journal of Marketing for Higher Education 7, no. 2, 57-73.

Krone, F., M.Gilly, V.Zeithaml and C.W. Lamb. 1981. Factors influencing the Graduate Business School decision. American Marketing Services Proceedings, 453-456. 
Malaysia Department of Statistics. 2009. Unpublished data.

Mansor A.T. and K.A. Tan. 2009. Predictors of career indecision among Malaysian undergraduate students. European Journal of Social Sciences 8, no. 2:

Mincer, J. 1958. Investment in human capital and personal income distribution. The Journal of Political Economy 66, no. 4 : 281-302.

Moogan, Y.J., S.Baron and K. Harris. 1999. Decision-making behaviour of potential higher education students. Higher Education Quarterly 53, no. 3, 211-228.

Moogan, Y.J. 2010. An analysis of school pupils' (with low social economic status) perceptions of university, regarding programmes of study. Educational Studies, iFirst Article:1-14.

McDonough, P.M. 1997. Choosing colleges: How social class and schools structure opportunity. Albany: State University of New York Press.

Perez, P.A and P. M. McDonough. 2008. Understanding Latina and Latino college choice: A social capital and chain migration analysis. Journal of Hispanic Higher Education 7, no. 3: 249-265.

Riggs, R.O and W.L. Lewis. 1980. Applicability of marketing research to student recruitment. Journal of College Student Personnel 21, 467-468.

Roberts, D and A. Allen. 1997. Young applicant's perceptions of higher education. Leeds, UK: Heist.

Stearns, E., S. Potochnick, S. Moller, and S. Southworth. 2010. High school course-taking and post-secondary institutional selectivity. Research in Higher Education 51, no. 4: 366-395.

Strasser S., C. Ozgur and D.L. Schroeder. 2002. Selecting a business college major. Mid-American Journal of Business 17, no. 2: 47-56.

Yamamoto, G.T. 2006. University evaluation-selection: a Turkish case. International Journal of Educational Management 20, no. 7: 559-569. 